\title{
Direito (Subjetivo) ao Acordo de Não Persecução Penal e Controle Judicial: Reflexões à Luz da Teoria dos Direitos Fundamentais
}

\author{
Right (Subjective) to the Criminal Non-Prosecution \\ Agreement and Judicial Control: Reflections in the \\ Light of the Fundamental Rights Theory
}

Augusto César Leite de Resende ${ }^{\mathbf{1}}$

Universidade Tiradentes, Aracaju, Sergipe, Brasil

aclresende@bol.com.br

http://lattes.cnpq.br/5491873833306228

http://orcid.org/0000-0003-1719-8685

\begin{abstract}
Resumo: A Lei n 13.964/2019, denominada de "Pacote Anticrime", regulamentou o instituto despenalizador do "Acordo de Não Persecução Penal". Com a vigência da legislação relativa ao benefício legal, instaurou-se no cenário jurídico nacional grande controvérsia acerca da natureza jurídica do novo instituto e sobre a possibilidade de controle jurisdicional da recusa do Ministério Público em oferecê-lo. Por essa razão, o presente artigo científico tem por objetivo analisar, a partir de uma pesquisa dedutiva, bibliográfica e legislativa, a natureza jurídica do "Acordo de Não Persecução Penal" e sobre a possibilidade de controle jurisdicional da recusa do Ministério Público em propor ao investigado tal benefício, à luz da teoria dos direitos fundamentais. Para concluir, ao final, que o "Acordo de Não Persecução Penal" é direito subjetivo da pessoa investigada e que o Poder Judiciário pode controlar a legalidade do ato de recusa do benefício pelo Ministério Público, concedendo-o se atendidos os requisitos legais.
\end{abstract}

1 Doutor em Direito pela Pontifícia Universidade Católica do Rio Grande do Sul PUCRS. Mestre em Direito pela Pontifícia Universidade Católica do Paraná - PUCPR. Especialista em Direito Público pela Universidade Sul de Santa Catarina UNISUL. Professor de Direitos Humanos e Fundamentais do Curso de Graduação em Direito da Universidade Tiradentes - UNIT. Promotor de Justiça em Sergipe. 
Palavras-chave: Direito fundamental à liberdade de locomoção; Acordo de Não Persecução Penal; Direito subjetivo; Controle judicial.

ABSTRACT: Act N. 13.964/2019, called the "Anti-Crime Package", regulated the decriminalizing institute of the "Criminal Non-Prosecution Agreement". With the legislation on the legal benefit in force, arise a great controversy in the national legal scene about the legal nature of the new institute and about the possibility of judicial control of the refusal of the Ministry for Public Affairs to offer it. For this reason, the purpose of this scientific article is to analyze, based on deductive, bibliographic and legislative research, the legal nature of the "Criminal Non-Prosecution Agreement" and on the possibility of judicial control over the refusal of the Ministry for Public Affairs to propose to the investigated such a benefit, in the light of the theory of fundamental rights. To conclude, in the end, that the "Criminal Non-Prosecution Agreement" is the subjective right of the investigated person and that the Judiciary can control the legality of the act of refusing the benefit by the Public Ministry, granting it if the legal requirements are fulfilled.

Keywords: Fundamental right to freedom of movement; Criminal NonProsecution Agreement; Subjective right; Judicial review.

SuMÁRIO: Introdução; 1. Direito fundamental à liberdade de locomoção; 2. Direito subjetivo ao Acordo de Não Persecução Penal; 3. Controle judicial do Acordo de Não Persecução Penal; Considerações finais; Referências.

\section{INTRODUÇÃO}

O Conselho Nacional do Ministério Público introduziu no ordenamento jurídico brasileiro, através da Resolução n ${ }^{\circ} 181 / 2017$, a figura despenalizadora do "Acordo de Não Persecução Penal”, que teve sua constitucionalidade questionada perante o Supremo Tribunal Federal pelo Conselho Federal da Ordem dos Advogados do Brasil e pela Associação dos Magistrados do Brasil, por meio das ações direta de inconstitucionalidade de número 5.790 e 5.793, sob o argumento de que o Conselho Nacional do Ministério Público não tem competência para legislar sobre matéria processual penal. Posteriormente, a Lei $n^{\circ} 13.964 / 2019$, denominada 
de "Pacote Anticrime", inseriu no Código de Processo Penal o art. 28-A, que versa sobre o instituto já mencionado, entrando em vigor no dia 23 de janeiro de 2020 .

Com a vigência da legislação relativa ao "Acordo de Não Persecução Penal”, instaurou-se no cenário jurídico nacional grande controvérsia acerca da natureza do novo instituto e sobre a possibilidade de controle jurisdicional da recusa do Ministério Público em oferecê-lo.

Por essa razão, o Conselho Nacional de Procuradores-Gerais do Ministério Público dos Estados e da União (CNPG), associação nacional, sem fins lucrativos, da qual fazem parte os Procuradores-Gerais de Justiça dos Ministérios Públicos dos Estados e da União, e criada com o objetivo de defender os princípios, prerrogativas e funções institucionais do Ministério Público ${ }^{2}$, aprovou enunciados produzidos pelo Grupo Nacional de Coordenadores de Centro de Apoio Criminal (GNCCRIM) que visam orientar os membros do Ministério Público brasileiro na interpretação da Lei Anticrime (Lei no 13.964/2019) ${ }^{3}$.

Diante das incertezas e dúvidas existentes quanto à aplicação da chamada Lei Anticrime, os enunciados acima mencionados têm forte força persuasiva sobre a conduta funcional dos membros do Ministério Público, na medida em que espelham o pensamento jurídico do Ministério Público brasileiro sobre os dispositivos da novel legislação penal e processual penal, notadamente quanto ao "Acordo de Não Persecução Penal”, especificamente no que se refere à natureza do instituto e à exigibilidade judicial do direito, permitindo-se, com isso, a construção de uma visão "institucionalizada" e, possivelmente, parcial da medida.

Em suma, o "Acordo de Não Persecução Penal" é direito subjetivo do investigado? O Poder Judiciário pode conceder, ainda que à revelia do Parquet, titular da ação penal, o benefício do "Acordo de Não Persecução Penal"? Assim, o presente artigo científico tem por objetivo analisar a natureza jurídica do "Acordo de Não Persecução Penal" e

2 Disponível em: https://www.cnpg.org.br/index.php/quem-somos/o-que-e-o -cnpg. Acesso em: 18 de fev. 2020.

3 Disponível em: https://www.mpse.mp.br/index.php/2020/01/24/cnpg -aprova-enunciados-produzidos-pelo-gnccrim-para-orientar-a-atuacao-dosmembros-do-mp-sobre-a-lei-anticrime/. Acesso em: 18 fev. 2020. 
sobre a possibilidade de controle jurisdicional da recusa do Ministério Público em propor ao investigado tal benefício, à luz da teoria dos direitos fundamentais.

Nesse contexto, analisar-se-á a fundamentalidade formal e material do direito à liberdade de locomoção. Em seguida, tratar-se-á da natureza do instituto do "Acordo de Não Persecução Penal" enquanto direito subjetivo do investigado. Por fim, refletir-se-á sobre a possibilidade do controle judicial da recusa do Ministério Público em oferecer ao interessado o benefício.

Para tanto, utilizar-se-á o método dedutivo, partindo-se de argumentos gerais, aceitos como verdadeiros, para, em seguida, chegar à proposição objetivada na presente pesquisa científica. A tipologia de pesquisa será a bibliográfica e a documental, mediante análise da legislação em vigor e de material doutrinário já publicado, especialmente livros, teses e artigos científicos.

Ao final, conclui-se que o "Acordo de Não Persecução Penal" é direito subjetivo da pessoa investigada e que o Poder Judiciário pode exercer o controle de legalidade do ato de recusa do benefício pelo Ministério Público, concedendo-o, por consequência, ao interessado.

\section{Direito fundamental À liberdade de locomoção}

Os direitos fundamentais podem ser classificados em: direitos formalmente fundamentais e direitos materialmente fundamentais. A fundamentalidade formal dos direitos está, na lição de Ingo Wolfgang Sarlet, diretamente relacionada ao direito constitucional positivo e resulta do regime jurídico especial de proteção estabelecido pela Constituição ${ }^{4}$, regime este que os alça à condição de direitos de natureza constitucional, de limites ao poder constituinte derivado reformador e de normas diretamente aplicáveis ${ }^{5}$.

\footnotetext{
4 SARLET, Ingo Wolfgang. A eficácia dos direitos fundamentais: uma teoria geral dos direitos fundamentais na perspectiva constitucional. 12. ed. Porto Alegre: Livraria do Advogado, 2015, p. 78.

5 Ibidem, p. 75-76.
} 
Os direitos fundamentais meramente formais são aqueles reconhecidos como tais pela Carta $\mathrm{Magna}^{6}$, independentemente de seu conteúdo ${ }^{7}$. Nesse sentido, tem-se que são direitos formalmente fundamentais, embora alguns também sejam materialmente fundamentais, os positivados no Título II da Constituição Federal de 1988, quais sejam: a) direitos e deveres individuais; b) direitos e deveres coletivos; c) direitos sociais; d) direitos à nacionalidade; e e) direitos políticos.

De qualquer forma, registre-se que o rol do referido Título II da Carta Magna não é taxativo, eis que existem direitos material e formalmente fundamentais dispersos na Constituição, vale dizer, para além dos artigos $5^{\circ}$ a 17 do Texto Constitucional ${ }^{8}$. Os direitos fundamentais não são apenas aqueles consagrados e reconhecidos formalmente na Constituição, uma vez que esta admite a existência dos chamados direitos materialmente fundamentais, que poderão ser identificados a partir do conceito aberto de direitos fundamentais adotado pelo art. $5^{\circ}, \S 2^{\circ}$, da Constituição Federal.

Tal dispositivo constitucional possibilita o reconhecimento de direitos fundamentais positivados em outras partes do texto constitucional ou em tratados internacionais e até mesmo na identificação de direitos fundamentais não-escritos, sejam eles implícitos na Carta Magna ou decorrentes do regime e princípios adotados por ela, Constituição?.

A definição de direito fundamental, proposta por Ingo Wolfgang Sarlet ${ }^{10}$, permite ao intérprete a identificação e, consequentemente, a efetivação e a proteção de direitos formal e materialmente fundamentais, direitos apenas formalmente fundamentais e direitos fundamentais exclusivamente materiais.

Porém, a identificação e a caracterização de um direito dotado de fundamentalidade material não são tarefas fáceis para o intérprete e

6 Ibidem, p. 76.

7 ALEXY, Robert. Teoria dos direitos fundamentais. Tradução de Virgílio Afonso da Silva. São Paulo: Malheiros, 2008, p. 68.

8 SARLET, Ingo Wolfgang. A eficácia dos direitos fundamentais: uma teoria geral dos direitos fundamentais na perspectiva constitucional. 12. ed. Porto Alegre: Livraria do Advogado, 2015, p. 117.

9 Ibidem, p. 76.

10 Ibidem, p. 78. 
aplicador do direito, pois não decorrem apenas da simples leitura do texto constitucional, eis que "somente uma análise do seu conteúdo permite a verificação de sua fundamentalidade material"11.

Assim, reconhecem-se direitos que, apesar de não positivados formalmente no rol do Título II da Constituição Federal, por seu conteúdo, importância e significado, podem ser considerados fundamentais e, por isso mesmo, inseridos na Carta Constitucional, produzindo todos os efeitos jurídicos ${ }^{12}$.

A regra do art. $5^{\circ}, \S 2^{\circ}$, da Constituição da República traduz a ideia de que além de um conceito formal de Constituição há um conceito material ${ }^{13}$, no sentido de que a constitucionalização contemporânea do direito, fortemente influenciada pelo pós-positivismo, não se limita ao texto formal e expresso da Constituição, abarcando princípios implícitos e os tratados internacionais de direitos humanos ${ }^{14}$, que passam a ser elementos integrantes da Constituição material, conceituada por José Joaquim Gomes Canotilho como:

[...] o conjunto de fins e valores constitutivos do princípio efectivo da unidade e permanência de um ordenamento jurídico (dimensão objectiva), e o conjunto de forças políticas e sociais (dimensão subjectiva) que exprimem esses fins ou valores, assegurando a estes a respectiva prossecução e concretização, algumas vezes para além da própria constituição escrita. Ao contrário do que muitas vezes se pensa e vê escrito, a constituição material não se reconduz a um simples "poder de facto" ("relações de poder e influência", "facto político puro"), pois a constituição material tem também uma função ordenadora. A chamada força normativa de constituição (K. Hesse) pressupõe, a maior parte das vezes, a vontade de constituição, ou seja, a explicitação na constituição

11 Ibidem, p. 76.

12 Ibidem, p. 80.

13 Ibidem, p. 80.

14 SCHIER, Paulo Ricardo. Filtragem constitucional e ADPF 138. Gazeta do Povo. Curitiba, 21 de dezembro de 2015. Disponível em: https://www.gazetadopovo.com.br/vida-publica/justica-e-direito/artigos/filtragem-constitucional-e-adpf-378-1841mh3iwmui5eu9c76tn7ib9/. Acesso em: 10 fev. 2020. 
escrita ou formal do complexo de fins e valores agitados pelas constelações políticas e sociais a nível da constituição material ${ }^{15}$.

A Constituição material é composta pelas normas relativas à estrutura do Estado, à organização dos poderes e aos direitos e garantias fundamentais ${ }^{16}$ e permite a abertura da Constituição a outros direitos fundamentais não elencados no Título II da Carta Magna e aos direitos humanos positivados em tratados internacionais.

A Constituição é um sistema aberto de regras e princípios ${ }^{17}$ que vai além da Constituição formal, fruto do poder constituinte. A Carta Magna de 1988 reconhece expressamente, em seu art. $5^{\circ}$, § $2^{\circ}$, a existência de outras fontes do direito fora da própria Constituição ${ }^{18}$, o que possibilita a incorporação ao direito brasileiro de normas constitucionais não expressas no texto constitucional. A esse respeito Estefânia Maria de Queiroz Barboza ensina:

No Brasil, é possível identificar a existência de uma Constituição invisível especialmente no que diz respeito aos princípios implícitos, aos princípios gerais do direito e aos direitos humanos e fundamentais, tendo em vista o que estabelece o art. $5^{\circ}, \S 2^{\circ}$, da Carta Constitucional ${ }^{19}$.

A abertura do sistema constitucional impede que a dedução de direitos fundamentais implícitos ou decorrentes possa ser realizada unicamente a partir de uma visão cartesiana-reducionista do ordenamento jurídico e da ciência jurídica, eis que o Direito, enquanto objeto e conhecimento, é aberto e, por isso, influencia e é influenciado pelos demais

15 CANOTILHO, José Joaquim Gomes. Direito constitucional e teoria da Constituição. 7. ed. Coimbra: Almedina, 2011, p. 1.139.

16 SARLET, Ingo Wolfgang; MARINONI, Luiz Guilherme; MITIDIERO, Daniel. Curso de direito constitucional. 4. ed., São Paulo: Saraiva, 2015, p. 71.

17 MIRANDA, Jorge. Teoria do Estado e da Constituição. Rio de Janeiro: Forense, 2011, p. 204.

18 BARBOZA, Estefânia Maria de Queiroz. Precedentes judiciais e segurança jurídica: fundamentos e possibilidades para a jurisdição constitucional brasileira. São Paulo: Saraiva, 2014, p. 178.

19 Ibidem, p. 179. 
campos do conhecimento científico e pelo ambiente em que se insere, razão pela deve ser compreendido indissociavelmente de seu contexto ${ }^{20}$.

As normas jurídicas, que estão dentro do sistema jurídico, têm o seu conteúdo dependente de interações com o meio e com os outros sistemas sociais ${ }^{21}$. Assim,

[...] o significado de determinadas normas jurídicas pode depender, em maior ou menor medida, de elementos que pertencem ao ambiente do sistema jurídico [...] em casos como esse, a compreensão do sistema depende da compreensão do meio - inclusive, eventualmente, de compreensão cientificamente especializada não jurídica ${ }^{22}$.

O significado dos textos normativos, inclusive os relacionados a direitos fundamentais, emerge das interações existentes no interior do sistema jurídico-normativo e entre o sistema jurídico, o ambiente e os demais sistemas sociais, sendo insuficiente a compreensão dos textos normativos unicamente através da análise científica do ordenamento jurídico ${ }^{23}$.

A interpretação dos enunciados normativos não depende apenas do texto, mas da sua conversação com outros dispositivos jurídicos, com os demais saberes científicos e com o contexto histórico, social, cultural, econômico e político, de modo que esses fatos não podem ser compreendidos isoladamente ${ }^{24}$.

Não é por outro motivo que os direitos fundamentais são variáveis no tempo e no espaço, aliado ao fato de que a cláusula de abertura material do art. $5^{\circ}, \S 2^{\circ}$ propicia um processo permanente de identificação de novos

20 MORIN, Edgar. Introdução ao pensamento complexo. 4. ed. Porto Alegre: Sulina, 2011, p. 47.

${ }^{21}$ FOLLONI, André. Ainda o reducionismo no direito. Disponível em: https:// complexidade.net/2015/02/02/ainda-o-reducionismo-no-direito/. Acesso em: 11 fev. 2020.

22 Ibidem.

23 Ibidem.

24 FOLLONI, André. O papel da ciência do direito tributário no desenvolvimento tributário. In: MURTA, Antônio Carlos Diniz; BALTHAZAR, Ubaldo Cesar; FEITOSA, Raymundo Juliano Rego (Coord.). Direito Tributário. Florianópolis: CONPEDI, 2014, p. 194-215, p. 206-207. 
direitos ${ }^{25}$ e de transformação de conteúdo dos velhos direitos. Além do mais, a dignidade da pessoa humana não é, ela mesma, um direito fundamental26, mas, enquanto princípio estruturante do Estado brasileiro, é a fonte e o fundamento dos direitos fundamentais ${ }^{27} \mathrm{e}$ dos direitos humanos ${ }^{28}$. O jurista gaúcho Ingo Wolfgang Sarlet define a dignidade da pessoa humana como:

[...] a qualidade intrínseca e distintiva reconhecida em cada ser humano que o faz merecedor do mesmo respeito e consideração por parte do Estado e da comunidade, implicando, neste sentido, um complexo de direitos e deveres fundamentais que assegurem a pessoa tanto contra todo e qualquer ato de cunho degradante e desumano, como venham a lhe garantir as condições existenciais mínimas para uma vida saudável, além de propiciar e promover sua participação ativa co-responsável nos destinos da própria existência e da vida em comunhão com os demais seres humanos, mediante o devido respeito aos demais seres que integram a rede da vida ${ }^{29}$.

O princípio da dignidade da pessoa humana atua como critério de identificação de direitos materialmente fundamentais eventualmente existentes na ordem jurídica do Brasil, de modo que é verdadeira "fonte jurídico-positiva dos direitos fundamentais, dando-lhes unidade e coerência” ${ }^{30}$. E nesse

25 SARLET, Ingo Wolfgang. A eficácia dos direitos fundamentais: uma teoria geral dos direitos fundamentais na perspectiva constitucional. 12. ed. Porto Alegre: Livraria do Advogado, 2015, p. 85.

26 SARLET, Ingo Wolfgang. Dignidade da pessoa humana e direitos fundamentais na Constituição Federal de 1988. 9. ed. Porto Alegre: Livraria do Advogado, 2012, p. 84.

27 Ressalte-se que nem todos os direitos fundamentais estão diretamente fundados na dignidade humana (SARLET, Ingo Wolfgang. A eficácia dos direitos fundamentais: uma teoria geral dos direitos fundamentais na perspectiva constitucional. 12. ed. Porto Alegre: Livraria do Advogado, 2015, p. 97). Tema que aqui não será desenvolvido porque fugiria dos propósitos do presente artigo científico.

28 SARLET, Ingo Wolfgang. Dignidade da pessoa humana e direitos fundamentais na Constituição Federal de 1988. 9. ed. Porto Alegre: Livraria do Advogado, 2012, p. 95. Ibidem, p. 73.

30 SARLET, Ingo Wolfgang. A eficácia dos direitos fundamentais: uma teoria geral dos direitos fundamentais na perspectiva constitucional. 12. ed. Porto Alegre: Livraria do Advogado, 2015, p. 110. 
contexto, pode-se afirmar que há, no ordenamento jurídico brasileiro, um verdadeiro direito fundamental material e formal à liberdade de locomoção, nos termos do art. $5^{\circ}$, inciso XV, da Carta Constitucional, que é uma das mais importantes e elementares liberdades individuais da pessoa humana ${ }^{31}$.

\section{Direito subjetivo ao Acordo de Não Persecução Penal}

Vinicius Vasconcellos define a justiça penal consensual como um "[...] modelo que se pauta pela aceitação (consenso) de ambas as partes - acusação e defesa - a um acordo de colaboração processual com o afastamento do réu de sua posição de resistência, em regra impondo encerramento antecipado, abreviação, supressão integral ou de alguma fase do processo, fundamentalmente com o objetivo de facilitar a imposição de uma sanção penal com algum percentual de redução, o que caracteriza o benefício ao imputado em razão da renúncia ao devido transcorrer do processo penal com todas as garantias a ele inerentes"32.

A partir da definição acima exposta, percebe-se que o "Acordo de Não Persecução Penal”, inserido no art. 28-A do Código de Processo Penal pela Lei ${ }^{\circ} 13.964 / 2019$, amplia a justiça consensual no âmbito do processo penal brasileiro, somando-se à transação penal e à suspensão condicional do processo criminal $^{33}$, tendo sido importado do plea bargaining anglo-americano ${ }^{34}$.

${ }^{31}$ SARLET, Ingo Wolfgang; MARINONI, Luiz Guilherme; MITIDIERO, Daniel. Curso de direito constitucional. 4. ed., São Paulo: Saraiva, 2015, p. 532.

32 VASCONCELLOS, Vinicius Gomes. Barganha e justiça criminal negocial: análise das tendências de expansão dos espaços de consenso no processo penal brasileiro. Dissertação (Mestrado em Direito) - Pontifícia Universidade Católica do Rio Grande do Sul, Porto Alegre, 2014, p. 322.

33 LOPES JÚNIOR, Aury; JOSITA, Higyna. Questões polêmicas do acordo de não persecução penal. Disponível em: https://www.conjur.com.br/ 2020-mar-06/limite-penal-questoes-polemicas-acordo-nao-persecucao-penal. Acesso em: 18 abr. 2020.

34 RIBEIRO, Leo Maciel Junqueira; COSTA, Victor Cezar Rodrigues da Silva. Acordo de não persecução penal: um caso de direito penal das consequências levado às últimas consequências. Revista Brasileira de Ciências Criminais, São Paulo, ano 27, v. 161, p. 249-276, 2019, p. 259. 
O novel instrumento despenalizador é um instrumento voltado à obtenção do consenso entre o Ministério Público e o sujeito passivo da persecução penal, aumentando, desse modo, a justiça consensual penal no Brasil ${ }^{35}$. A esse respeito, “[...] atualmente existem no processo penal brasileiro alguns institutos que se caracterizam como acordos entre acusação e defesa a partir do consentimento do réu: transação penal, suspensão condicional do processo, acordo de não persecução penal e colaboração premiada" ${ }^{36}$. Diante da marca consensual do "Acordo de Não Persecução Penal", há quem afirme, inclusive, tratar-se de um negócio jurídico que obsta o oferecimento da denúncia ${ }^{37}$.

Nesse contexto, com a sua criação normativa, instalou-se controvérsia acerca na natureza jurídica do "Acordo de Não Persecução Penal" no cenário nacional, de um lado há aqueles que defendem que o assim designado ANPP é direito subjetivo do investigado e de outro lado existem posições que sustentam se tratar apenas de uma faculdade do Ministério Público e não propriamente um direito público subjetivo do interessado oponível contra o Estado.

Higyna Josita e Lopes Jr. sustentam que as regras e a principiologia próprias da suspensão condicional do processo podem ser aplicadas, no que couber, ao "Acordo de Não Persecução Penal”, uma vez que os dois institutos são instrumentos de promoção da justiça criminal consensuada, de modo que o referido benefício legal é uma mera faculdade do Ministério Público, não se constituindo em um direito subjetivo, ainda que o acusado atenda os requisitos legais do

35 ANDRADE, Mauro F.; BRANDALISE, Rodrigo S. Observações preliminares sobre o acordo de não persecução penal: da inconstitucionalidade à inconsistência argumentativa. Revista da Faculdade de Direito da UFRGS, Porto Alegre, n. 37, p. 239-262, dez. 2017, p. 243.

36 VASCONCELLOS, Vinicius Gomes. Colaboração premiada e negociação na justiça criminal brasileira: acordos para a ampliação de sansão penal consentida pelo réu no processo penal. Revista Brasileira de Ciências Criminais, São Paulo, v. 166, p. 241-271, abr. 2020.

37 CARNEIRO, Andréa Walmsley Soares. Acordo de não-persecução penal: constitucionalidade do método negocial no processo penal. Delictae: Revista de Estudos Interdisciplinares sobre o Delito, Belo Horizonte, v. 4, n. 7, p. 23-41, jul./dez/ 2019, p. 37. 
benefício, devendo, porém, a recusa ser fundamentada pelo órgão acusador $^{38}$.

Emerson Garcia, ao analisar o instituto do "Acordo de Não Persecução Penal” sob a égide da Resolução n 181/2017 do Conselho Nacional do Ministério Público, afirmou claramente que "a celebração do acordo de não persecução penal é uma faculdade do Ministério Público, não um direito subjetivo do réu" 39 .

Américo Bêde Júnior e Alexandre de Castro Coura lecionam que não é possível afirmar a existência no sistema jurídico brasileiro de um direito subjetivo do acusado ao acordo de colaboração premiada, por entenderem que a "lógica do acordo parte da premissa da disponibilidade do oferecimento de proposta, que possui caráter eminentemente funcional, do ponto de vista da produção de provas lícitas e úteis ao autor da ação penal” ${ }^{40}$, raciocínio este que pode ser perfeitamente aplicável ao "Acordo de Não Persecução Penal”.

A partir da premissa da natureza consensual da suspensão condicional do processo, o Supremo Tribunal Federal fixou entendimento de que é imprescindível o assentimento do Ministério Público para a sua concessão e da da transação penal, não podendo o Poder Judicário conceder tais benefícios à revelia do titular da ação penal, não se revelando, portanto, direitos subjetivos do acusado ${ }^{41}$.

Nessa perspectiva, poder-se-ia utilizar a ratio da decisão do Pretório Excelso para justificar que o “Acordo de Não Persecução Penal” não seria direito público subjetivo do investigado, tendo-se em vista a natureza

38 LOPES JÚNIOR, Aury; JOSITA, Higyna. Questões polêmicas do acordo de não persecução penal. Disponível em: https://www.conjur.com.br/ 2020-mar-06/limite-penal-questoes-polemicas-acordo-nao-persecucao-penal. Acesso em: 18 abr. 2020. GARCIA, Emerson. O acordo de não persecução penal passível de ser celebrado pelo Ministério Público: breves reflexões. Revista do Ministério Público do Rio de Janeiro, Rio de Janeiro, n. 68, p. 39-42, abr./jun. 2018, p. 42. BÊDE JÚNIOR, Américo; COURA, Alexandre de Castro. Atuação do juiz no acordo de colaboração premiada e a garantia dos direitos fundamentais do acusado no processo penal brasileiro. Revista dos Tribunais, São Paulo, ano 105 , v. 969 , p. 149-159, jul. 2016, n.p.

${ }^{41}$ BRASIL. Supremo Tribunal Federal. Inquérito 3.438, Rel. Min. Rosa Weber, DJe 10.02.2015. 
consensual no novo instituto e a titularidade da ação penal ser, nos casos de crime de ação penal pública, do Ministério Público.

Porém, sob as bases de uma hermenêutica constitucional e da leitura do art. 28-A do Código de Processo Penal conforme os direitos fundamentais, o “Acordo de Não Persecução Penal” se revela uma posição jurídica que decorre do direito fundamental à liberdade de locomoção, constituindo-se, portanto, em direito público subjetivo do investigado.

Um "direito fundamental completo é um feixe de posições de direitos fundamentais" ${ }^{42}$, o que significa dizer que "os direitos fundamentais constituem posições jurídicas complexas, no sentido de poderem conter direitos, liberdades, pretensões e poderes da mais diversa natureza" ${ }^{43} \cdot \mathrm{Na}$ lição de Daniel Wunder Hachem e de Alan Bonat, é possível distinguir um direito fundamental "como um todo" e as pretensões jurídicas que decorrem desse direito ${ }^{44}$.

Segundo Ingo Wolfgang Sarlet, "todo direito fundamental possui um âmbito de proteção (um campo de incidência normativa ou suporte fático)" ${ }^{45}$ e, nesse diapasão, "abrange os diferentes pressupostos fáticos instituídos pela respectiva norma jurídica" ${ }^{46}$, vale dizer, "trata-se do bem jurídico protegido" ${ }^{47}$.

O âmbito de proteção diz "respeito àquilo que a norma de direito fundamental garante prima facie" ${ }^{48}$, alcançando, portanto, atos, fatos, estados e posições jurídicas que podem ser extraídos e, desse modo, protegidos

42 ALEXY, Robert. Teoria dos direitos fundamentais. Tradução de Virgílio Afonso da Silva. São Paulo: Malheiros, 2008, p. 249.

43 SARLET, Ingo Wolfgang. A eficácia dos direitos fundamentais: uma teoria geral dos direitos fundamentais na perspectiva constitucional. 12. ed. Porto Alegre: Livraria do Advogado, 2015, p. 159.

44 HACHEM, Daniel Wunder; BONAT, Alan. O ensino médio como parcela do direito ao mínimo existencial. Revista Opinião Jurídica, Fortaleza, ano 14, n. 18, p. 144-176, jan./jun. 2016, p. 149.

45 SARLET, Ingo Wolfgang. A eficácia dos direitos fundamentais: uma teoria geral dos direitos fundamentais na perspectiva constitucional. 12. ed. Porto Alegre: Livraria do Advogado, 2015, p. 404.

46 Ibidem, p. 405.

47 Ibidem, p. 405.

48 ALEXY, Robert. Teoria dos direitos fundamentais. Tradução de Virgílio Afonso da Silva. São Paulo: Malheiros, 2008, p. 302. 
pela norma de direito fundamental ${ }^{49}$. E o direito fundamental à liberdade de locomoção, na qualidade de um direito fundamental completo ou "como um todo", é positivado na Constituição Federal de 1988 de modo aberto e genérico, compreendendo todas as possíveis manifestações da liberdade individual de ir e vir, abarcando, portanto, um feixe complexo de posições subjetivas ${ }^{50}$. O seu âmbito de proteção alcança, destarte, todas as condutas e institutos que promovam ou ampliem de alguma maneira a esfera de liberdade de circulação do indivíduo.

A liberdade de locomoção compreende, parafraseando Robert Alexy ${ }^{51}$, todas as ações, características e posições jurídicas, inclusive aquelas criadas pelo direito infraconstitucional que proporcione o direito de ir e vir das pessoas humanas, sobretudo porque compete ao Estado dar condições materiais de exercício do referido direito fundamental, especialmente nas esferas da organização e do procedimento ${ }^{52}$, como são as regulamentações normativas relativas à prisão e aos benefícios despenalizadores.

Deste modo, o assim designado "Acordo de Não Persecução Penal”, criado, inicialmente, em 2017, pelo Conselho Nacional do Ministério Público, e, atualmente, instituído pelo art. 28-A do Código de Processo Penal, encontra-se compreendido no âmbito de proteção do direito fundamental à liberdade de locomoção. Nas palavras de Ingo Wolfgang Sarlet,

[...] o âmbito de proteção de um direito fundamental não é determinado pela mera designação do bem protegido (dignidade humana, vida, integridade corporal etc.), mas será obtido, em geral, mediante a cuidadosa interpretação e análise, que leve em conta todos os elementos do suporte fático, visto que apenas quando da determinação do âmbito de proteção do direito, estará definido se alguma situação ou bem jurídico se encontra jusfundamentalmente

49 SILVA, Virgílio Afonso da. Direitos fundamentais: conteúdo essencial, restrições e eficiência. 2. ed. São Paulo: Malheiros, 2017, p. 72.

50 SARLET, Ingo Wolfgang; MARINONI, Luiz Guilherme; MITIDIERO, Daniel. Curso de direito constitucional. 4. ed., São Paulo: Saraiva, 2015, p. 533.

51 ALEXY, Robert. Teoria dos direitos fundamentais. Tradução de Virgílio Afonso da Silva. São Paulo: Malheiros, 2008, p. 303.

52 SARLET, Ingo Wolfgang; MARINONI, Luiz Guilherme; MITIDIERO, Daniel. Curso de direito constitucional. 4. ed., São Paulo: Saraiva, 2015, p. 534. 
assegurada, assim como será possível determinar qual ou mesmo quais direitos fundamentais estão em causa ${ }^{53}$.

O processo penal brasileiro passa por mudanças mediante a ampliação dos institutos de justiça negocial e, não é por outro motivo que, a Lei ${ }^{\circ} 13.964 / 2019$ tem como um dos seus principais pilares a ampliação da justiça criminal consensual no Brasil ${ }^{54}$, especialmente com a institucionalização do Acordo de Não Persecução Penal, que impede o início da ação penal em desfavor do autor do fato criminoso e, se cumpridas as suas condições, acarreta a extinção da punibilidade.

Com efeito, o direito processual penal brasileiro é regido pela regra da obrigatoriedade da ação penal pública, que pode ser, na lição de Vinicius Vasconcellos, excepcionada, de acordo com as hipóteses e condições previstas na legislação ${ }^{55}$. $\mathrm{O}$ art. 28-A do Código de Processo Penal criou mais um espaço de oportunidade ou, em outras palavras, não obrigatoriedade da ação penal pública, na medida em que permite ao Ministério Público, não sendo o caso de arquivamento, abster-se de iniciar a persecução criminal, desde que presentes os requisitos para a concessão do "Acordo de Não Persecução Penal”.

Consagra-se, destarte, o princípio da "oportunidade legalmente regulada" ${ }^{6}$, uma vez que se está diante de um mecanismo consensual em que o decurso da persecução penal não segue seu transcurso legalmente estabelecido, em razão de um acordo entre as partes ${ }^{57}$ e não por causa da vontade exclusiva do Ministério Público.

53 SARLET, Ingo Wolfgang. A eficácia dos direitos fundamentais: uma teoria geral dos direitos fundamentais na perspectiva constitucional. 12. ed. Porto Alegre: Livraria do Advogado, 2015, p. 408.

54 ARAS, Vladimir. O acordo de não persecução penal após a lei 13.964/2019. In: CAVALCANTE, André Clark Nunes; LIMA, Antônio Edilberto Oliveira; PINHEIRO, Igor Pereira; VACCARO, Luciano; ARAS, Vladimir (Orgs.). Lei anticrime comentada. LEME: JH Mizuno, 2020, p. 129-204, p. 129.

55 VASCONCELLOS, Vinicius Gomes de. Barganha e justiça criminal negocial: análise das tendências de expansão dos espaços de consenso no processo penal brasileiro. São Paulo: IBCCRIM, 2015, p. 58.

56 Ibidem, p. 51.

57 Ibidem, p. 58. 
A partir das premissas acima indicadas, afirma-se que a esfera normativa do art. $5^{\circ}$, inciso XV, da Carta Constitucional de 1988 abrange o benefício legal do “Acordo de Não Persecução Penal”, na medida em que se trata de instrumento despenalizador, impeditivo da persecução penal em juízo e, desse modo, obstante da imposição da pena privativa de liberdade. O instituto amplia a esfera de proteção da liberdade de locomoção da pessoa, conferindo-lhe obstáculos ou guard rails ao seu cerceamento em virtude da prática de crime sem violência ou grave ameaça e com pena mínima inferior a quatro anos.

O “Acordo de Não Persecução Penal”, enquanto posição jurídica integrante do âmbito de proteção do direito fundamental à liberdade de circulação, apresenta uma estrutura triádica, composta por um sujeito ativo, o investigado; um sujeito passivo, o Estado; e um objeto, que é a conduta prescrita pela norma jurídica, no caso, o art. 28-A do Código de Processo Penal, que deve ser realizada pelo Ministério Público a favor do investigado, revelando-se, assim, como um direito que tem o sujeito ativo suscetível de ser exercido sobre o sujeito passivo ${ }^{58}$.

A ampliação da justiça criminal consensual com o chamado ANPP não impede o seu reconhecimento como direito público subjetivo do autor do fato. Afirmar que o "Acordo de Não Persecução Penal” é um ato negocial e, concomitantemente, um direito subjetivo do investigado não é contraditório. A partir da lição de Nereu Giacomolli, sobre a natureza jurídica da suspensão condicional do processo penal, percebe-se que a essência do novel benefício legal não reside na bilateralidade, apesar de o acordo depender, a princípio, do consenso entre o órgão acusador e o investigado, uma vez que se o Ministério Público não o tiver proposto, quando presente os requisitos legais, a defesa poderá postulá-lo em juízo $0^{59}$.

A Lei $n^{\circ}$ 13.964/2019 estabeleceu os requisitos do "Acordo de Não Persecução Penal”. Segundo o art. 28-A do Código de Processo Penal, não sendo caso de arquivamento e tendo o investigado confessado formal

58 PULIDO, Carlos Bernal. El principio de proporcionalidad y los derechos fundamentales: el principio de proporcionalidad como criterio para determinar el contenido de los derechos fundamentales vinculante para el legislador. 4. ed. Bogotá: Universidad Externado de Colombia, 2014, pos. 1589. Kindle.

59 GIACOMOLLI, Nereu José. Juizados especiais criminais: Lei 9.099/95: abordagem crítica. 3. ed. Porto Alegre: Livraria do Advogado Editora, 2009, p. 201. 
e circunstancialmente a prática de infração penal sem violência ou grave ameaça e com pena mínima inferior a quatro anos, o Ministério Público poderá propor o benefício legal, desde que necessário e suficiente para a reprovação e a prevenção do crime. A propósito:

Os requisitos legais são de índole subjetiva e objetiva:

a) não ser cabível o arquivamento do caso;

b) tratar-se de crime praticado sem violência ou grave ameaça contra pessoa;

c) tratar-se de crime com pena mínima inferior a 4 anos de prisão;

d) haver confissão formal e circunstanciada do investigado;

e) o acordo representar uma solução "necessária e suficiente para a reprovação e prevenção do crime";

f) não ser cabível a transação penal da Lei 9.099/1995;

g) não ser o investigado reincidente ou criminoso "profissional";

h) não ter sido o investigado beneficiado por outro acordo penal nos 5 anos anteriores à prática da infração penal;

i) não se tratar de crime de violência doméstica ou familiar ou de gênero ${ }^{60}$.

Se preenchidos todos os requisitos legais, o Ministério Público tem o dever de oferecer a proposta de "Acordo de Não Persecução Penal”, eis que se trata de direito subjetivo do investigado. É grande a controvérsia sobre a natureza jurídica do instituto processual consensual retromencionado, havendo vozes, como dito alhures, que sustentam que "o acusado não tem direito subjetivo ao acordo de não persecução penal" ${ }^{61}$ ou que "o acordo de não persecução penal é faculdade do Ministério Público" ${ }^{62}$.

60 Ibidem, p. 156.

61 Ibidem, p. 170.

62 Enunciado N. ${ }^{\circ} 19$ editado pelo Conselho Nacional de Procuradores-Gerais dos Ministérios Públicos dos Estados e da União - CNPG. Disponível em: https://www.cnpg.org.br/images/arquivos/gndh/documentos/enunciados/ GNCCRIM_Enunciados.pdf. Acesso em $10 \mathrm{fev} .2020$. 
O “Acordo de Não Persecução Penal” é um instituto que, como já antes ressaltado, insere-se no âmbito de proteção do direito fundamental à liberdade de locomoção, de modo que é defeso ao Ministério Público, enquanto órgão do Estado, promover restrições arbitrárias e subjetivas ao gozo do direito.

Os direitos fundamentais se apresentam como direitos de defesa e como direitos a prestações, sendo que estes últimos se subdividem em direitos de prestação fática e de prestação jurídica. A diferença entre direitos de defesa e direitos de prestação reside no comando prescritivo das normas jurídicas definidoras de direitos fundamentais, ou seja, nas obrigações ou proibições que recaem sobre os destinatários dos direitos fundamentais ${ }^{63}$.

$\mathrm{Na}$ qualidade de direitos de defesa, os direitos fundamentais impõem ao Estado um dever de abstenção, proibindo-o de praticar atos de ingerência ou restrição na autonomia pessoal e na propriedade privada ${ }^{64}$. O papel dos direitos fundamentais, nessa condição, é a de assegurar ao indivíduo a possibilidade de realizar ou não uma ação de acordo com sua vontade, respeitados os limites legais e constitucionais ${ }^{65}$. Cria-se, assim, uma esfera de proteção à liberdade pessoal imune à atividade estatal abusiva, isto é, contrária à Constituição $0^{66}$.

Por outro lado, na condição de direitos prestacionais, os direitos fundamentais obrigam a Administração a implementar os meios e as condições necessárias para que as pessoas possam efetivamente exercer suas liberdades fundamentais ${ }^{67}$. São direitos que se realizam por meio do Estado $^{68}$, exigindo-se, portanto, do Poder Público uma postura ativa no sentido de executar prestações fáticas e jurídicas em favor dos indivíduos.

63 CARA, Juan Carlos Gavara de. La dimensión objetiva de los derechos sociales. Barcelona: Bosch Editor, 2010, p. 19.

64 PIEROTH, Bodo; SCHLINK, Bernhard. Direitos fundamentais. Tradução de Antônio Francisco de Sousa e de Antônio Franco. São Paulo: Saraiva, 2012, p. 62.

65 CARA, Juan Carlos Gavara de. La dimensión objetiva de los derechos sociales. Barcelona: Bosch Editor, 2010, p. 17.

66 SARLET, Ingo Wolfgang. A eficácia dos direitos fundamentais: uma teoria geral dos direitos fundamentais na perspectiva constitucional. 12. ed. Porto Alegre: Livraria do Advogado, 2015, p. 175.

67 Ibidem, p. 191.

68 PIEROTH, Bodo; SCHLINK, Bernhard. Direitos fundamentais. Tradução de Antônio Francisco de Sousa e de Antônio Franco. São Paulo: Saraiva, 2012, p. 63. 
O direito à liberdade de locomoção opera, concomitantemente, como um direito de defesa e como um de direito de prestação, possuindo, portanto, dupla dimensão positiva e negativa ${ }^{69}$. Nessa esteira, o Ministério Público não pode deixar de propor o "Acordo de Não Persecução Penal" ao interessado se presentes todos os requisitos legais do benefício, sob argumento de conveniência e oportunidade para a promoção da ação penal em juízo, sendo-lhe vedado criar obstáculos arbitrários e, especialmente, subjetivos à celebração do acordo. O direito à liberdade de locomoção não é absoluto. Porém, enquanto direito de hierarquia constitucional, somente pode ser restringido por normas constitucionais ou em virtude delas $^{70}$. Os direitos fundamentais podem ser limitados e restringidos em caráter geral pela própria Constituição ou normas infraconstitucionais, cuja criação é autorizada pela Carta Magna, bem como por outros direitos fundamentais ou por bens constitucionalmente tutelados, independentemente de expressa autorização constitucional para a restrição $0^{71}$. As colisões entre direitos fundamentais ou conflitos entre esses direitos e outros bens constitucionais legitimam o estabelecimento de restrições a direitos fundamentais não submetidos a reserva constitucional expressa nesse sentido ${ }^{72}$.

No que se refere ao "Acordo de Não Persecução Penal", a legislação processual penal regulamentou a forma de exercício do benefício, estabelecendo, inclusive, os seus requisitos, o que é perfeitamente compatível com a Constituição Federal ${ }^{73}$. Porém, a negativa do "Acordo de Não Persecução Penal”, quando atendidos seus pressupostos legais, caracteriza clara atividade erosiva do Estado ao direito de liberdade do

69 SARLET, Ingo Wolfgang; MARINONI, Luiz Guilherme; MITIDIERO, Daniel. Curso de direito constitucional. 4. ed., São Paulo: Saraiva, 2015, p. 533-534.

70 ALEXY, Robert. Teoria dos direitos fundamentais. Tradução de Virgílio Afonso da Silva. São Paulo: Malheiros, 2008, p. 286.

71 SARLET, Ingo Wolfgang. A eficácia dos direitos fundamentais: uma teoria geral dos direitos fundamentais na perspectiva constitucional. 12. ed. Porto Alegre: Livraria do Advogado, 2015, p. 409-410.

72 NOVAIS, Jorge Reis. As restrições aos direitos fundamentais não expressamente autorizadas pela Constituição. 2. ed. Coimbra: Wolters Kluwer: Coimbra Editora, 2010, p. 547.

73 SILVA, Virgílio Afonso da. Direitos fundamentais: conteúdo essencial, restrições e eficiência. 2. ed. São Paulo: Malheiros, 2017, p. 104-105. 
investigado, que ficará sujeito à imposição de pena privativa de liberdade ao final da ação penal.

É verdade que a legislação ordinária conferiu ao Ministério Público certa liberdade interpretativa para analisar, em um primeiro momento, o requisito subjetivo da "suficiência do acordo para a prevenção e repressão do crime", uma vez que se está diante de um conceito jurídico indeterminado ${ }^{74}$, isto é, vago ou ambíguo, cujo significado será construído a partir das circunstâncias do caso concreto. Mas mesmo nesse caso, a análise não é e não deve ser solipsista, que acaba, como adverte Lênio Luiz Streck, "em decisionismos e arbitrariedades interpretativas, isto é, em um mundo jurídico em que cada um interpreta como (melhor) lhe convém"75.

O membro do Ministério Público deve suspender seus pré-juízos para interpretar a legislação ${ }^{76}$, mais precisamente o art. 28-A do Código de Processo Penal. A atribuição de sentido aos pressupostos legais do “Acordo de Não Persecução Penal” não é um ato de escolha do órgão acusador a partir do seu sentido de justiça pessoal, ideologia ou crença religiosa ou política ${ }^{77}$, isto é, "ele não está autorizado a atribuir sentidos de forma discricionária/arbitrária"78. Para tanto, deve ser orientado pela ideia do direito como integridade. Nas palavras de Ronald Dworkin: "Segundo o direito como integridade, as proposições jurídicas são verdadeiras se constam, ou se derivam, dos princípios de justiça, equidade e devido processo legal que oferecem a melhor interpretação construtiva da prática jurídica"79.

${ }^{74}$ Karl Engisch define conceito jurídico indeterminado como aquele "conceito cujo conteúdo e extensão são em larga medida incertos” (ENGISCH,Karl. Introdução ao pensamento jurídico. Tradução de J. Baptista Machado, 11. ed. Lisboa: Fundação Calouste Gulbenkian, 2014, p. 208).

75 STRECK, Lenio Luiz. Aplicar a "letra da lei" é uma atitude positivista? Revista Novos Estudos Jurídicos, Vol. 15 - n. 1 - p. 158-173, jan./abr. 2010, p. 162.

76 STRECK, Lenio Luiz. Compreender direito: hermenêutica. São Paulo: Tirant lo Blanch, 2019, p. 47.

STRECK, Lenio Luiz. Dicionário de hermenêutica: quarenta temas fundamentais da teoria do direito à luz da crítica hermenêutica do Direito. Belo Horizonte: Letramento: Casa do Direito, 2017, p. 58.

79 DWORKIN, Ronald. O império do direito. Tradução de Jefferson Luiz Camargo. 2. ed. São Paulo: Martins Fontes, 2007, p. 272. 
A história é particularmente importante para a concepção do direito como integridade porque "os direitos e deveres decorrem de decisões coletivas tomadas no passado e que, por esse motivo, permitem ou exigem coerção" ${ }^{80}$. O direito é prática interpretativa, que deve levar em consideração a história institucional da comunidade, a partir da ideia de romance em cadeia, de modo que a interpretação do direito aplicável ao caso concreto deve se filiar à cadeia histórica de decisões políticas e jurídicas ${ }^{81}$, levando-se em consideração, portanto, a Constituição, a legislação infraconstitucional, os precedentes e as circunstâncias peculiares do caso concreto.

Parafraseando Aury Lopes Júnior, a liberdade interpretativa do Ministério Público deve conviver com o direito público subjetivo do investigado, de modo que, ao Parquet, cabe unicamente analisar se estão preenchidos os requisitos legais e negociar sobre as condições a serem estabelecidas, propondo ao interessando, cumulativa ou alternativamente, por exemplo, a reparação do dano, pagamento de prestação pecuniária e prestação de serviços à comunidade, não lhe competindo decidir sobre o cabimento ou não do "Acordo de Não Persecução Penal" 82.

O "Acordo de Não Persecução Penal" pauta-se, enquanto instrumento de exercício da justiça criminal negocial, "pelo incentivo da participação dos atores processuais, na busca de uma convergência de vontades"83 e, nesse contexto, se presentes os pressupostos legais, o Ministério Público tem o dever de negociar com o investigado os termos do acordo, embora se reconheça, com espeque em Nereu Giacomolli ${ }^{84}$, que nem sempre o acordo representará um convênio entre as partes,

${ }^{80}$ Ibidem, p. 273-274.

81 VIANA, Ulisses Schwarz. O direito no pensamento de Dworkin. In: ALMEIDA FILHO, Agassiz; LEITE, George Salomão; ABBOUD, Georges (orgs.). Ronald Dworkin: direito, política e pessoa humana. Florianópolis: Tirant Lo Blanch, 2018, p. 17-35, p. 31.

82 LOPES JÚNIOR, Aury. Direito processual penal. 16. ed. São Paulo: Saraiva, 2019, p. 759.

8383 VASCONCELLOS, Vinicius Gomes de. Barganha e justiça criminal negocial: análise das tendências de expansão dos espaços de consenso no processo penal brasileiro. São Paulo: IBCCRIM, 2015, p. 56.

${ }^{84}$ GIACOMOLLI, Nereu José. Juizados especiais criminais: Lei 9.099/95: abordagem crítica. 3. ed. Porto Alegre: Livraria do Advogado Editora, 2009, p. 202. 
pois poderá ser concedido pelo Poder Judiciário a partir da postulação da defesa, conforme se verá mais adiante.

A interpretação do art. 28-A do Código de Processo Penal e, por consequência, a decisão do órgão acusador quanto ao cabimento ou não do "Acordo de Não Persecução Penal" deve tomada com base unicamente em argumentos jurídicos, afastando-se senso pessoal de justiça ou de visão de mundo do membro do Ministério Público. Nesse contexto, a interpretação do dispositivo legal acima mencionado deve se basear no princípio de interpretação extensiva dos direitos fundamentais e o princípio de interpretação restritiva das limitações aos direitos fundamentais, de modo a estender protetivamente o campo de aplicação dos direitos reconhecidos ${ }^{85}$, inclusive o "Acordo de Não Persecução Penal". Nessa esteira, há uma verdadeira presunção de que o benefício legal é suficiente para a prevenção e repressão do crime, recaindo sobre o Estado, isto é, sobre o Ministério Público o ônus de demonstrar, hermenêutica, exaustiva e justificadamente, no caso concreto, que a medida despenalizadora não é suficiente para a repressão e prevenção do delito. Em suma: o ônus argumentativo é do Estado e não do investigado.

Se a medida, à luz das peculiaridades do caso, não for suficiente para a prevenção e repressão do crime, estar-se-á diante da ausência de um dos requisitos legais para o não oferecimento da proposta de não persecução penal. A negativa não recai sobre a justificativa que não se trata de um direito subjetivo, mas na ausência de um dos requisitos legais exigidos para a concessão do benefício.

Enfim, não há para o Ministério Público uma faculdade e muito menos discricionariedade, a partir de critérios de conveniência e oportunidade, para a concessão ou não do "Acordo de Não Persecução Penal", eis que se presentes os requisitos objetivos e subjetivos a formulação da proposta é obrigatória, sob pena de constrangimento ilegal, competindo, destarte, ao Estado demonstrar a ausência dos requisitos legais autorizadores do "Acordo de Não Persecução Penal".

85 AGUILAR CAVALLO, Gonzalo. Juiz constitucional e diálogo jurisdicional multinível: a experiência chilena. Revista de Investigações Constitucionais, Curitiba, vol. 6, n. 1, p. 61-89, jan./abr. 2019, p. 70. 


\section{Controle judicial do Acordo de Não Persecução Penal}

O Supremo Tribunal Federal tem firme posição de que não cabe ao Poder Judiciário conceder, à revelia do Ministério Público, titular da ação penal, os benefícios da transação penal e da suspensão condicional do processo $^{86}$, por entender que tais benefícios dependem do assentimento do Ministério Público, que está estreitamente conectado à titularidade da ação penal pública, que a Constituição confiou a ele com exclusividade. Com base nisso, parte da literatura jurídica nacional ensina que "haveremos de reconhecer que também para o ANPP a titularidade é exclusiva do Ministério Público e, por conta disso, não pode haver acordo de não persecução sem a anuência do Parquet e do investigado" ${ }^{87}$.

O Superior Tribunal de Justiça também tem entendimento consolidado no sentido de que "a suspensão condicional do processo não é direito subjetivo do acusado, mas sim um poder-dever do Ministério Público, titular da ação penal, a quem cabe, com exclusividade, analisar a possibilidade de aplicação do referido instituto" 88 .

As posições contrárias ao controle jurisdicional partem da premissa de que a suspensão condicional do processo, a transação penal e o “Acordo de Não Persecução Penal" são institutos próprios da justiça penal consensual, de modo que o magistrado, para manter sua imparcialidade, deve-se manter distante das negociações e como a Constituição conferiu a titularidade da ação penal ao Ministério Público, cabe com exclusividade

86 BRASIL. Supremo Tribunal Federal. Súmula n. 696. "Reunidos os pressupostos legais permissivos da suspensão condicional do processo, mas se recusando o Promotor de Justiça a propô-la, o Juiz, dissentindo, remeterá a questão ao Procurador-Geral, aplicando-se por analogia o art. 28 do Código de Processo Penal”. Brasília, DF: Supremo Tribunal Federal, 2003. Disponível em: http://www.stf.jus.br/portal/jurisprudencia/menuSumarioSumulas.asp?sumula=2666. Acesso em: 15 fev. 2020.

87 ARAS, Vladimir. O acordo de não persecução penal após a lei 13.964/2019. In: CAVALCANTE, André Clark Nunes; LIMA, Antônio Edilberto Oliveira; PINHEIRO, Igor Pereira; VACCARO, Luciano; ARAS, Vladimir (Orgs.). Lei anticrime comentada. LEME: JH Mizuno, 2020, p. 129-204, p. 171.

BRASIL. Superior Tribunal de Justiça. AgRg no HC 504074/DF. Agravante: Rodrigo Cavalcante de Oliveira. Agravado: Ministério Público Federal e Ministério Público do Estado de São Paulo. Relator: Ministro Antônio Saldanha Palheiro. Brasília, DF, 13 de agosto de 2019. Diário da Justiça Eletrônico. Brasília. 
ao órgão ministerial analisar a possibilidade ou não de propor os referidos benefícios legais.

A Lei $n^{\circ}$ 13.964/2019 instituiu um controle judicial do "Acordo de Não Persecução Penal”, mas mitigado e insuficiente para a garantia do exercício da liberdade de locomoção do autor do fato. O art. 28-A, § 14, do Código de Processo Penal aduz textualmente que "no caso de recusa, por parte do Ministério Público, em propor o acordo de não persecução penal, o investigado poderá requerer a remessa dos autos a órgão superior, na forma do art. 28 deste Código", ou seja, o magistrado, se for provocado pelo investigado, ordenará, caso não concorde com as razões lançadas pelo membro do Parquet para a recusa, a remessa dos autos ao Procurador-Geral de Justiça, em se tratando de Ministério Público estadual, ou à Câmara de Coordenação e Revisão Criminal, no caso do Ministério Público Federal. No entanto, a última palavra, seguindo a lógica do art. 28 do Código de Processo Penal, será sempre do Ministério Público ${ }^{89}$.

Contudo, tal entendimento não merece prosperar porque impede a tutela judicial do direito fundamental à liberdade de locomoção do indivíduo, deixando-o à mercê de eventuais subjetivismos e arbitrariedades por parte do Ministério Público. Com efeito, a jurisdição constitucional foi inicialmente teorizada como mecanismo de garantia da supremacia do texto formal da Constituição $0^{90}$, mas, no constitucionalismo contemporâneo do século XXI, a jurisdição constitucional se apresenta também como importante instrumento de concretização dos direitos fundamentais.

As atrocidades perpetradas pelo nazismo e fascismo durante a da Segunda Guerra Mundial mostraram à comunidade jurídica que a legitimidade da lei e dos demais atos estatais não mais poderia ser aferida unicamente com base em sua regularidade formal, de modo que se faz mister também a análise da compatibilidade material dos atos do Estado com os direitos fundamentais positivados na Constituição $0^{91}$. Afinal,

89 LIMA, Marcellus Polastri. O acordo de não persecução penal no processo penal brasileiro. Revista Magister de Direito Penal e Processual Penal, Porto Alegre, v. 15, n. 87, p. 5-20, 2019, p. 12.

90 KELSEN, Hans. Jurisdição constitucional. 3. ed. São Paulo: WMF Martins Fontes, 2013, p. 148.

91 ABBOUD, Georges. Processo constitucional brasileiro. São Paulo: Revista dos Tribunais, 2016, p. 104. 
como diz Paulo Bonavides, "a época constitucional que vivemos é a dos direitos fundamentais que sucede à época da separação de poderes"92. A esse respeito, Ingo Wolfgang Sarlet ensina que:

[...] os direitos fundamentais, na condição de normas que incorporam determinados valores e decisões essenciais que caracterizam sua fundamentalidade, servem, na qualidade de normas de direito objetivo e independentemente de sua perspectiva subjetiva, como parâmetro para o controle de constitucionalidade das leis e demais atos normativos estatais ${ }^{93}$.

Os direitos fundamentais são verdadeiros limites à atuação estatal e à deliberação democrática, de modo que, nesse contexto, a jurisdição constitucional passou a ter grande relevância como instrumentos de proteção e promoção de tais direitos. O juiz constitucional atua, através da interpretação dos textos normativos e da força de suas decisões, como garantidor da força normativa da Constituição e da efetividade dos direitos fundamentais.

Em síntese, o controle judicial dos atos estatais pode e deve ser utilizado para a salvaguarda dos direitos fundamentais ${ }^{94}$. A jurisdição constitucional tem, portanto, a relevante missão de proteger os direitos fundamentais dos indivíduos, sejam eles de primeira, segunda ou terceira dimensão. Segundo Georges Abboud, as funções da justiça constitucional são:

- Limitar o Poder Público - último ponto em que ocorre o controle dos atos do Poder Executivo;

92 BONAVIDES, Paulo. Jurisdição constitucional e legitimidade: algumas observações sobre o Brasil. Estudos Avançados, São Paulo, v. 18, n. 51, p. 127-150, ago. 2004, p. 127.

93 SARLET, Ingo Wolfgang. A eficácia dos direitos fundamentais: uma teoria geral dos direitos fundamentais na perspectiva constitucional. 12. ed. Porto Alegre: Livraria do Advogado, 2015, p. 153.

94 Não se desconhece a existência de corrente doutrinária defensora da chamada "democracia procedimental", para quem o Poder Judiciário somente deve atuar para garantir o livre exercício da democracia ou dos direitos de participação política, de modo que o controle de constitucionalidade das leis seria antidemocrático. Neste sentido confira-se: HABERMAS, Jürgen. Direito e democracia: entre facticidade e validade. Vol. I, 2. ed. Tradução de Flávio Beno Siebeneichler. Rio de Janeiro: Tempo Brasileiro, 2012. 
- Garantir a existência das minorias e assegurar proteção dos direitos fundamentais previstos no texto constitucional e nos tratados internacionais que o Brasil seja signatário;

- Corrigir equívocos e omissões do Poder Legislativo, função que a jurisdição constitucional adquiriu em virtude do recrudescimento das decisões manipulativas e aditivas;

- Conferir, em termos dogmáticos, coerência e garantir a preservação da própria autonomia do Direito, mais precisamente da própria Constituição Federal, pela jurisprudência advinda da jurisdição constitucional, desde que consistentemente fundamentada ${ }^{95}$.

A jurisdição constitucional funciona, assim, como instrumento de controle do poder estatal em prol dos direitos fundamentais e da dignidade humana. $O$ processo constitucional tem nítido caráter contramajoritário porque se destina a limitar o poder da maioria em benefício dos direitos fundamentais, notadamente das minorias, que funcionam como verdadeiros trunfos contra a vontade da maioria ${ }^{96}$, exteriorizada não somente nas leis infraconstitucionais, mas também nos atos praticados pelos agentes públicos, inclusive, membros do Ministério Público. Na lição de Ronald Dworkin,

A teoria constitucional em que se baseia nosso governo não é uma simples teoria da supremacia das maiorias. A Constituição, e particularmente a Bill of Rights (Declaração de Direitos e Garantias), destina-se a proteger os cidadãos (ou grupos de cidadãos) contra certas decisões que a maioria pode querer tomar, mesmo quando essa maioria age visando o que considera ser o interesse geral ou comum ${ }^{97}$.

A forma de investidura dos Ministros do Supremo Tribunal Federal é justamente a nomeação, por livre escolha do Presidente da República, e não a eleição popular para que a Corte possa exercer

\footnotetext{
95 ABBOUD, Georges. Processo constitucional brasileiro. São Paulo: Revista dos Tribunais, 2016, p. 110.

96 Ibidem, p. 115.

97 DWORKIN, Ronald. Levando os direitos a sério. Tradução de Nélson Boeira. 3. ed. São Paulo: WMF Martins Fontes, 2010, p. 208-209.
} 
com imparcialidade e técnica jurídica o seu importante mister contramajoritário, ainda que sua decisão possa desagradar grande parte da população nacional ${ }^{98}$.

O processo de escolha dos Ministros da Corte Suprema os impede, em tese, de temer eventual insatisfação popular com suas decisões ${ }^{99}$. Evidentemente que o Supremo Tribunal Federal poderá decidir em conformidade com a vontade da maioria, o que o Pretório Excelso não pode fazer é fundamentar suas decisões na opinião pública, posto que o Poder Judiciário decide, nos dizeres de Ronald Dworkin, com base em argumentos de princípios ${ }^{100}$. A esse respeito:

[...] o Tribunal deve tomar decisões de princípio, não de política - decisões sobre que direitos as pessoas têm sob nosso sistema constitucional, não decisões sobre como se promove melhor o bem-estar geral -, e que deve tomar essas decisões elaborando e aplicando a teoria substantiva da representação, extraída do princípio básico de que o governo deve tratar as pessoas como iguais ${ }^{101}$.

Os órgãos do Poder Judiciário devem proferir suas decisões com base em argumentos princípios ${ }^{102} \mathrm{e}$, sempre que assim procederem, poderão legitimamente afastar a aplicação de uma decisão majoritária contrária a direitos fundamentais ou à dignidade humana, uma vez que, como ensina Conrado Hübner Mendes, "levar direitos a sério exige tê-los como trunfos

98 ABBOUD, Georges. Processo constitucional brasileiro. São Paulo: Revista dos Tribunais, 2016, p. 117.

99 DWORKIN, Ronald. Uma questão de princípio. Tradução de Luís Carlos Borges. 2. ed. São Paulo: Martins Fontes, 2005, p. 28.

${ }^{100}$ DWORKIN, Ronald. Levando os direitos a sério. Tradução de Nélson Boeira. 3. ed. São Paulo: WMF Martins Fontes, 2010, p. 132.

${ }^{101}$ DWORKIN, Ronald. Uma questão de princípio. Tradução de Luís Carlos Borges. 2. ed. São Paulo: Martins Fontes, 2005, p. 101.

${ }^{102}$ Ronald Dworkin não aceita decisões judiciais proferidas com fundamento em argumentos de política, entendendo como tal "aquele tipo de padrão que estabelece um objetivo a ser alcançado, em geral uma melhoria em algum aspecto econômico, político ou social da comunidade" (DWORKIN, Ronald. Levando os direitos a sério. Tradução de Nélson Boeira. 3. ed. São Paulo: WMF Martins Fontes, 2010, p. 36). 
(rights as trumps) perante a maioria [...] um trunfo, nesta concepção, não permuta, não se negocia nem se barganha, mas se respeita"103.

A democracia não se resume à vontade maioria, mas combina procedimento e substância, forma e conteúdo, eis que o procedimento não pode tomar qualquer decisão ${ }^{104}$, mas somente aquela que respeite a dignidade humana e os direitos fundamentais. Assim, não se pode deixar a "última palavra" sobre a concessão ou não do "Acordo de Não Persecução Penal” ao Ministério Público, excluindo da apreciação do Poder Judiciário lesão ou ameaça de lesão ao direito fundamental à liberdade de locomoção.

As regras se aplicam por meio da subsunção, ou seja, se a regra é válida e estão presentes os pressupostos de fato que nela se subsumem, a regra deve ser aplicada. Nesse contexto, se preenchidos os requisitos legais, o Ministério Público tem o dever de propor o "Acordo de Não Persecução Penal”. E em caso de omissão ilegal ou abusiva, a supremacia dos direitos fundamentais e da dignidade humana dão legitimidade ao controle judicial dos atos e omissões emanados do Ministério Público em descompasso com o direito fundamental à liberdade de circulação e princípios constitucionais, desde que os órgãos do Poder Judiciário profiram suas decisões com base em argumentos de princípios ${ }^{105}$.

Em suma, a recusa do Ministério Público em oferecer o "Acordo de Não Persecução Penal” pode ser objeto de controle judicial por meio da garantia fundamental do habeas corpus, instrumento processual adequado para assegurar a plena efetividade do direito à liberdade de locomoção.

Negar a possibilidade de controle jurisdicional à recusa do Ministério Público caracteriza, inclusive, ilícito internacional da República Federativa do Brasil, ante a clara violação ao direito humano à proteção judicial, positivado no art. 25 da Convenção Americana sobre Direitos Humanos, que diz que toda pessoa tem direito a um recurso simples e

${ }^{103}$ MENDES, Conrado Hübner. Controle de constitucionalidade e democracia. Rio de Janeiro: Elsevier, 2008, p. 37.

${ }^{104}$ Ibidem, p. 34.

${ }^{105}$ KOZICKI, Katya; BARBOZA, Estefânia Maria de Queiroz. Jurisdição constitucional brasileira: entre constitucionalismo e democracia. Revista Sequência, Florianópolis, n. 56, p. 151-176, jun. 2008, p. 161. 
rápido ou a qualquer outro recurso efetivo, perante os juízes ou tribunais competentes, que a proteja contra atos que violem seus direitos fundamentais reconhecidos pela Constituição, pela lei ou pelo próprio Pacto de San José da Costa Rica, mesmo quando tal violação seja cometida por pessoas que estejam atuando no exercício de suas funções oficiais, o que é o caso dos membros do Ministério Público brasileiro.

O art. 25 da Convenção Americana consagra o direito de acesso à justiça, impondo ao Estado o dever de garantir acesso à administração da justiça para a tutela de direitos humanos, dentre os quais se insere o direito à liberdade de circulação ${ }^{106}$, ou seja, o Brasil tem a obrigação jurídica de oferecer, a todos os indivíduos submetidos à sua jurisdição, um procedimento jurisdicional efetivo contra atos atentatórios aos direitos humanos consagrados no Pacto de San José da Costa Rica, aos direitos fundamentais catalogados na Carta Constitucional e aos direitos reconhecidos pela legislação ordinária ${ }^{107}$.

O poder público tem a obrigação de garantir instrumentos judiciais simples, rápidos e efetivos para a proteção dos direitos da pessoa humana. Na lição de Flávia Piovesan e de Melina Girardi Fachin, o termo "recurso judicial”, consagrado no art. 25 do Paco de San José da Costa Rica, deve ser compreendido amplamente para se referir a qualquer remédio jurisdicional adequado à defesa de um direito ${ }^{108}$.

O “Acordo de Não Persecução Penal” é, como ressaltado alhures, uma medida despenalizadora, que incide sobre a punibilidade do agente e afasta a aplicação da sanção criminal, na medida em que o art. 28-A, § 13, do Código de Processo Penal dispõe que cumprido integralmente o acordo de não persecução penal, o juízo competente decretará a extinção da punibilidade.

106 PIOVESAN, Flávia; FACHIN, Melina Girardi; MAZZUOLI, Valério de Oliveira. Comentários à Convenção Americana sobre Direitos Humanos. Rio de Janeiro: Forense, 2019, p. 231.

107 ORGANIZAÇÃO DOS ESTADOS AMERICANOS. Corte Interamericana de Direitos Humanos. Caso Maldonado Ordoñez Vs. Guatemala. Sentença de 3 de maio de 2016. Série C, N. 311, par. 233.

108 PIOVESAN, Flávia; FACHIN, Melina Girardi; MAZZUOLI, Valério de Oliveira. Comentários à Convenção Americana sobre Direitos Humanos. Rio de Janeiro: Forense, 2019, p. 232. 
Nesse contexto, a negativa arbitrária do Ministério Público em oferecer ao investigado o "Acordo de Não Persecução Penal” caracterizará clara violação ao direito à liberdade de locomoção do indivíduo, razão pela qual este deve ter à sua disposição meios judiciais céleres e efetivos que lhe permitam impugnar a conduta omissiva do agente do Ministério Público violadora de sua liberdade.

No Brasil, o remédio constitucional que pode ser utilizado pelo interessado para garantir o "Acordo de Não Persecução Penal” é o habeas corpus, nos termos do art. $5^{\circ}$, inciso LXVIII, da Constituição Federal, eis que se trata de ação judicial de natureza célere, simples e eficaz para combater ilegalidade ou abuso de poder que acarrete coação ou violência à liberdade de locomoção da pessoa.

Inadmissível, portanto, a tese segundo o qual não cabe ao Poder Judiciário conceder, à revelia do Ministério Público, titular da ação penal, o benefício do "Acordo de Não Persecução Penal", ainda que seus requisitos legais estejam presentes no caso concreto, uma vez que "o Estado tem o dever de garantir um recurso efetivo quando violações forem cometidas pelos seus agentes, não podendo se furtar de aceitar ou prover remédios legais sob a alegação de que o agente cometeu o ato no estrito cumprimento de suas funções" 109 .

E mais, o Poder Judiciário brasileiro poderá analisar, por força do art. 25 da Convenção Americana sobre Direitos Humanos, os fundamentos fáticos e jurídicos alegados pelo Ministério Público para negar o “Acordo de Não Persecução Penal”, desde que submetidos à sua apreciação pelo interessado, sendo, deste modo, capaz de promover uma extensa revisão da decisão do Parquet, pois, como lecionam Flávia Piovesan e Melina Girardi Fachin:

[...] não há revisão judicial efetiva se o órgão judicial está impedido de determinar o objeto da controvérsia, como ocorre em casos em que o tribunal se declara limitado fática ou juridicamente à decisão do órgão administrativo. Desse modo, o recurso judicial deve ser capaz de promover uma extensa revisão de decisões administrativas, isto é, deve examinar todas as alegações e argumentos submetidos a seu conhecimento ${ }^{110}$.

\footnotetext{
${ }^{109}$ Ibidem, p. 242.

${ }^{110}$ Ibidem, p. 236.
} 
O controle judicial dos atos do Ministério Público que afetem ou possam afetar direitos ou benefícios reconhecidos em favor de pessoas privadas de liberdade ou que possam vir a ser sancionadas com pena privativa da liberdade, especialmente a recusa do "Acordo de Não Persecução Penal”, é um direito humano consagrado no art. 25 da Convenção Americana, que deve ser realizado por juízes ou tribunais imparciais e independentes, sob pena de responsabilização da República Federativa do Brasil no âmbito do Sistema Interamericano de Direitos Humanos.

O “Acordo de Não Persecução Penal” é direito público subjetivo do autor do fato. Direito subjetivo significa, em síntese, o poder, conferido pelo direito objetivo, de alguém exigir algo a outrem, sendo inerentes à condição de direito subjetivo o poder de exigir a sua realização e a sua sindicabilidade judicial ${ }^{111}$. Por sua vez, o termo direito subjetivo público se refere aos direitos dos cidadãos em face do Estado, regidos pelo direito público $^{112}$, inclusive, o direito processual penal. Vale dizer, os direitos públicos subjetivos atribuem

[...] ao cidadão, mediante previsões positivadas em lei, posições subjetivas que lhe resguardem um espaço de autonomia privada protegido contra a interferência estatal. As faculdades decorrentes de tais pretensões jurídicas permitem ao seu titular - o sujeito privado - exigir judicialmente a abstenção dos Poderes Públicos de invadir essa área de autonomia individual delimitada pelo próprio legislador ${ }^{113}$.

Nesse contexto, se presentes os pressupostos legais e o Ministério Público se recusar a negociar o "Acordo de Não Persecução Penal”, o Poder Judiciário tem a obrigação de garantir ao autor do fato o pleno e efetivo exercício de seu direito subjetivo, devendo o juiz propor o acordo ${ }^{114}$. A esse respeito,

${ }^{111}$ HACHEM, Daniel Wunder. São os direitos sociais “direitos públicos subjetivos"? Mitos e confusões na teoria dos direitos fundamentais. Revista de Estudos Constitucionais, Hermenêutica e Teoria do Direito (RECHTD), São Leopoldo, v. 11, n. 3, p. 404-436, set./dez. 2019, p. 411.

112 Ibidem, p. 413.

113 Ibidem, p. 414.

${ }^{114}$ LOPES JÚNIOR, Aury; JOSITA, Higyna. Questões polêmicas do acordo de não persecução penal. Disponível em: https://www.conjur.com. 
Não se trata, sublinhe-se, de atribuir ao juiz um papel de autor, ou mesmo de juiz--ator, característica do sistema inquisitório e incompatível com o modelo constitucional--acusatório por nós defendido. Nada disso. A sistemática é outra. O imputado postula o reconhecimento de um direito (o direito ao acordo de não persecução penal) que lhe está sendo negado pelo Ministério Público, e o juiz decide, mediante invocação. O papel do juiz aqui é o de garantidor da máxima eficácia do sistema de direitos do réu, ou seja, sua verdadeira missão constitucional ${ }^{115}$.

O investigado tem direito ao benefício do acordo quando preenchidos os pressupostos legais, de modo que atribuir ao Poder Judiciário poder de propor o benefício não viola, conforme lição de Aury Lopes Júnior, o sistema acusatório desenhado pela Constituição Federal de $1988^{116}$, eis que ao Poder Judiciário cumpre, no exercício de suas funções típicas, o dever-poder de determinar aos órgãos e entidades públicas e, evidentemente, aos particulares, a correta observância do ordenamento jurídico nacional, mormente quando não atendidos os direitos fundamentais consagrados na Carta Magna ${ }^{117}$, inclusive o direito à liberdade de locomoção e as posições jurídicas dele decorrentes, dentre os quais, como já ressaltado alhures, destaca-se o direito público subjetivo ao "Acordo de Não Persecução Penal”.

\section{ConsideraçõEs finAIS}

O presente trabalho de pesquisa teve por objetivo analisar, a partir de uma pesquisa dedutiva, bibliográfica e legislativa, sobre a natureza

br/2020-mar-06/limite-penal-questoes-polemicas-acordo-nao-persecucao -penal. Acesso em: 19 abr. 2020.

115 Ibidem.

${ }^{116}$ LOPES JÚNIOR, Aury. Direito processual penal. 16. ed. São Paulo: Saraiva, 2019, p. 768.

117 MARINONI, Luiz Guilherme. Teoria geral do processo. 6. ed., São Paulo: Revista dos Tribunais, 2012, p. 137. No mesmo sentido: RESENDE, Augusto César Leite de. O futuro do Sistema Interamericano de Direitos Humanos é doméstico: diálogo e cooperação entre ordens jurídicas como modelos de empoderamento da Corte Interamericana de Direitos Humanos. Tese (Doutorado em Direito) - Programa de Pós-Graduação em Direito da Pontifícia Universidade Católica do Rio Grande do Sul. Porto Alegre, p. 260, 2019, p. 121. 
jurídica do “Acordo de Não Persecução Penal”, criado pelo Conselho Nacional do Ministério Público, por meio da Resolução n 181/2017, e, posteriormente, institucionalizada pela Lei ${ }^{\circ} 13.964 / 2019$, denominada de "Pacote Anticrime", que inseriu o referido instituto despenalizador no Código de Processo Penal.

Partiu-se da premissa de que o "Acordo de Não Persecução Penal" amplia a esfera de proteção do direito fundamental à liberdade de locomoção, na medida em que afasta o jus puniendi do Estado e, por consequência, impede a aplicação da pena privativa de liberdade ao investigado que tenha preenchido os requisitos legais do benefício.

Nesse diapasão, o “Acordo de Não Persecução Penal” se revela verdadeiro direito subjetivo do investigado, de modo que o Ministério Público tem o dever de oferecer o benefício àquele que preencha os requisitos impostos pelo art. 28-A do Código de Processo Penal. E a omissão ilegal e abusiva do Ministério Público permite ao Poder Judiciário conceder, ainda que à revelia do Parquet, titular da ação penal, o benefício do "Acordo de Não Persecução Penal”, por se tratar de direito subjetivo do indivíduo e parcela do direito fundamental à liberdade de locomoção.

Os direitos fundamentais são verdadeiros limites à atuação do Estado, inclusive do Ministério Público, de modo que o controle judicial dos atos estatais pode e deve ser utilizado para a salvaguarda dos direitos da pessoa humana. Negar a possibilidade de controle jurisdicional à recusa do Ministério Público caracteriza, para além de ofensa ao princípio constitucional da inafastabilidade da jurisdição, ilícito internacional da República Federativa do Brasil, ante a clara violação ao direito humano à proteção judicial, positivado no art. 25 da Convenção Americana sobre Direitos Humanos.

O referido dispositivo do Pacto de San José da Costa Rica diz que toda pessoa tem direito a um recurso simples e rápido ou a qualquer outro recurso efetivo, perante os juízes ou tribunais competentes, que a proteja contra atos que violem seus direitos fundamentais reconhecidos pela Constituição, pela lei ou pela própria Convenção, mesmo quando tal violação seja cometida por pessoas que estejam atuando no exercício de suas funções oficiais, o que é o caso dos membros do Ministério Público brasileiro. 
O art. 25 da Convenção Americana consagra o direito de acesso à justiça, impondo ao Estado o dever de garantir acesso à administração da justiça para a tutela de direitos humanos, ou seja, o Brasil tem a obrigação jurídica de oferecer a todos os indivíduos submetidos à sua jurisdição, um procedimento jurisdicional efetivo contra atos atentatórios aos direitos humanos consagrados no Pacto de San José da Costa Rica, aos direitos fundamentais catalogados na Carta Constitucional e aos direitos reconhecidos pela legislação ordinária.

Assim, a recusa do Ministério Público em oferecer o "Acordo de Não Persecução Penal” pode ser objeto de controle judicial por meio da garantia fundamental do habeas corpus, instrumento processual adequado para assegurar a plena efetividade do direito à liberdade de locomoção. E, por consequência, o Poder Judiciário poderá conceder o benefício ao investigado, ainda que à revelia do Parquet, sempre que os requisitos legais estiverem presentes.

\section{REFERÊNCIAS}

ABBOUD, Georges. Processo constitucional brasileiro. São Paulo: Revista dos Tribunais, 2016.

AGUILAR CAVALLO, Gonzalo. Juiz constitucional e diálogo jurisdicional multinível: a experiência chilena. Revista de Investigações Constitucionais, Curitiba, vol. 6, n. 1, p. 61-89, jan./abr. 2019. https://doi.org/10.5380/rinc.v6i1.57697

ALEXY, Robert. Teoria dos direitos fundamentais. Tradução de Virgílio Afonso da Silva. São Paulo: Malheiros, 2008.

ANDRADE, Mauro F.; BRANDALISE, Rodrigo S. Observações preliminares sobre o acordo de não persecução penal: da inconstitucionalidade à inconsistência argumentativa. Revista da Faculdade de Direito da UFRGS, Porto Alegre, n. 37, p. 239-262, dez. 2017, p. 243. https://doi.org/10.22456/0104-6594.77401

ARAS, Vladimir. O acordo de não persecução penal após a lei 13.964/2019. In: CAVALCANTE, André Clark Nunes; LIMA, Antônio Edilberto Oliveira; PINHEIRO, Igor Pereira; VACCARO, Luciano; ARAS, Vladimir (Orgs.). Lei anticrime comentada. LEME: JH Mizuno, 2020, p. 129-204. 
BARBOZA, Estefânia Maria de Queiroz. Precedentes judiciais e segurança jurídica: fundamentos e possibilidades para a jurisdição constitucional brasileira. São Paulo: Saraiva, 2014.

BÊDE JÚNIOR, Américo; COURA, Alexandre de Castro. Atuação do juiz no acordo de colaboração premiada e a garantia dos direitos fundamentais do acusado no processo penal brasileiro. Revista dos Tribunais, São Paulo, ano 105, v. 969, p. 149-159, jul. 2016.

BONAVIDES, Paulo. Jurisdição constitucional e legitimidade: algumas observações sobre o Brasil. Estudos Avançados, São Paulo, v. 18, n. 51, p. 127-150, ago. 2004. https://doi.org/10.1590/s0103-40142004000200007

CANOTILHO, José Joaquim Gomes. Direito constitucional e teoria da Constituição. 7. ed. Coimbra: Almedina, 2011.

CARA, Juan Carlos Gavara de. La dimensión objetiva de los derechos sociales. Barcelona: Bosch Editor, 2010.

CARNEIRO, Andréa Walmsley Soares. Acordo de não-persecução penal: constitucionalidade do método negocial no processo penal. Delictae: Revista de Estudos Interdisciplinares sobre o Delito, Belo Horizonte, v. 4, n. 7, p. 23-41, jul./dez/ 2019. https://doi.org/10.24861/2526-5180.v4i7.102

DWORKIN, Ronald. Levando os direitos a sério. Tradução de Nelson Boeira. 3. ed. São Paulo: WMF Martins Fontes, 2010.

DWORKIN, Ronald. O império do direito. Tradução de Jefferson Luiz Camargo. 2. ed. São Paulo: Martins Fontes, 2007.

DWORKIN, Ronald. Uma questão de princípio. Tradução de Luís Carlos Borges. 2. ed. São Paulo: Martins Fontes, 2005.

ENGISCH, Karl. Introdução ao pensamento jurídico. Tradução de J. Baptista Machado, 11. ed. Lisboa: Fundação Calouste Gulbenkian, 2014.

FOLLONI, André. Ainda o reducionismo no direito. Disponível em: https:// complexidade.net/2015/02/02/ainda-o-reducionismo-no-direito/. Acesso em 11 fev. 2020.

FOLLONI, André. O papel da ciência do direito tributário no desenvolvimento tributário. In: MURTA, Antônio Carlos Diniz; BALTHAZAR, Ubaldo Cesar; FEITOSA, Raymundo Juliano Rego (Coord.). Direito Tributário. Florianópolis: CONPEDI, 2014, p. 194-215. 
GARCIA, Emerson. O acordo de não persecução penal passível de ser celebrado pelo Ministério Público: breves reflexões. Revista do Ministério Público do Rio de Janeiro, Rio de Janeiro, n. 68, p. 39-42, abr./jun. 2018.

GIACOMOLLI, Nereu José. Juizados especiais criminais: Lei 9.099/95: abordagem crítica. 3. ed. Porto Alegre: Livraria do Advogado Editora, 2009.

HABERMAS, Jürgen. Direito e democracia: entre facticidade e validade. Vol. I, 2. ed. Tradução de Flávio Beno Siebeneichler. Rio de Janeiro: Tempo Brasileiro, 2012.

HACHEM, Daniel Wunder. São os direitos sociais “direitos públicos subjetivos”? Mitos e confusões na teoria dos direitos fundamentais. Revista de Estudos Constitucionais, Hermenêutica e Teoria do Direito (RECHTD), São Leopoldo, v. 11, n. 3, p. 404-436, set./dez. 2019. https://doi.org/10.4013/rechtd.2019.113.08

HACHEM, Daniel Wunder; BONAT, Alan. O ensino médio como parcela do direito ao mínimo existencial. Revista Opinião Jurídica, Fortaleza, ano 14, n. 18, p. 144-176, jan./jun. 2016. https://doi.org/10.12662/2447-6641oj.v14i18. p144-176.2016

KELSEN, Hans. Jurisdição constitucional. Tradução do alemão de Alexandre Krug. 3. ed. São Paulo: WMF Martins Fontes, 2013.

KOZICKI, Katya; BARBOZA, Estefânia Maria de Queiroz. Jurisdição constitucional brasileira: entre constitucionalismo e democracia. Revista Sequência, Florianópolis, n. 56, p. 151-176, jun. 2008. https://doi.org/10.5007/2177-7055.2008v29n56p151

LIMA, Marcellus Polastri. O acordo de não persecução penal no processo penal brasileiro. Revista Magister de Direito Penal e Processual Penal, Porto Alegre, v. 15, n. 87 , p. 5-20, 2019, p. 12.

LOPES JÚNIOR, Aury. Direito processual penal. 16. ed. São Paulo: Saraiva, 2019.

LOPES JÚNIOR, Aury; JOSITA, Higyna. Questões polêmicas do acordo de não persecução penal. Disponível em: https://www.conjur.com.br/2020-mar-06/ limite-penal-questoes-polemicas-acordo-nao-persecucao-penal. Acesso em: 18 abr. 2020.

MARINONI, Luiz Guilherme. Teoria geral do processo. 6. ed., São Paulo: Revista dos Tribunais, 2012.

MENDES, Conrado Hübner. Controle de constitucionalidade e democracia. Rio de Janeiro: Elsevier, 2008.

MIRANDA, Jorge. Teoria do Estado e da Constituição. Rio de Janeiro: Forense, 2011. 
MORIN, Edgar. Introdução ao pensamento complexo. Tradução de Eliane Lisboa. 4. ed. Porto Alegre: Sulina, 2011.

NOVAIS, Jorge Reis. As restrições aos direitos fundamentais não expressamente autorizadas pela Constituição. 2. ed. Coimbra: Wolters Kluwer: Coimbra Editora, 2010.

ORGANIZAÇÃO DOS ESTADOS AMERICANOS. Corte Interamericana de Direitos Humanos. Caso Maldonado Ordoñez Vs. Guatemala. Sentença de 3 de maio de 2016. Série C, N. 311.

PIEROTH, Bodo; SCHLINK, Bernhard. Direitos fundamentais. Tradução de Antônio Francisco de Sousa e de Antônio Franco. São Paulo: Saraiva, 2012.

PIOVESAN, Flávia; FACHIN, Melina Girardi; MAZZUOLI, Valério de Oliveira. Comentários à Convenção Americana sobre Direitos Humanos. Rio de Janeiro: Forense, 2019.

PULIDO, Carlos Bernal. El principio de proporcionalidad y los derechos fundamentales: el principio de proporcionalidad como criterio para determinar el contenido de los derechos fundamentales vinculante para el legislador. 4. ed. Bogotá: Universidad Externado de Colombia, 2014. Kindle.

RESENDE, Augusto César Leite de. O futuro do Sistema Interamericano de Direitos Humanos é doméstico: diálogo e cooperação entre ordens jurídicas como modelos de empoderamento da Corte Interamericana de Direitos Humanos. Tese (Doutorado em Direito) - Programa de Pós-Graduação em Direito da Pontifícia Universidade Católica do Rio Grande do Sul. Porto Alegre, p. 260, 2019.

RIBEIRO, Leo Maciel Junqueira; COSTA, Victor Cezar Rodrigues da Silva. Acordo de não persecução penal: um caso de direito penal das consequências levado às últimas consequências. Revista Brasileira de Ciências Criminais, São Paulo, ano 27, v. 161, p. 249-276, 2019.

SARLET, Ingo Wolfgang. A eficácia dos direitos fundamentais: uma teoria geral dos direitos fundamentais na perspectiva constitucional. 12. ed. Porto Alegre: Livraria do Advogado, 2015.

SARLET, Ingo Wolfgang. Dignidade da pessoa humana e direitos fundamentais na Constituição Federal de 1988. 9. ed. Porto Alegre: Livraria do Advogado, 2012.

SARLET, Ingo Wolfgang; MARINONI, Luiz Guilherme; MITIDIERO, Daniel. Curso de direito constitucional. 4. ed., São Paulo: Saraiva, 2015.

SCHIER, Paulo Ricardo. Filtragem constitucional e ADPF 138. Gazeta do Povo. Curitiba, 21 de dezembro de 2015. Disponível em: https://www.gazetadopovo. 
com.br/vida-publica/justica-e-direito/artigos/filtragem-constitucional-e-adpf378-1841mh3iwmui5eu9c76tn7ib9/. Acesso em: 10 fev. 2020.

SILVA, Virgílio Afonso da. Direitos fundamentais: conteúdo essencial, restrições e eficiência. 2. ed. São Paulo: Malheiros, 2017.

STRECK, Lenio Luiz. Compreender direito: hermenêutica. São Paulo: Tirant lo Blanch, 2019.

STRECK, Lenio Luiz. Dicionário de hermenêutica: quarenta temas fundamentais da teoria do direito à luz da crítica hermenêutica do Direito. Belo Horizonte: Letramento: Casa do Direito, 2017.

STRECK, Lenio Luiz. Aplicar a "letra da lei" é uma atitude positivista? Revista Novos Estudos Jurídicos, Itajaí, v. 15, n. 1, p. 158-173, jan./abr. 2010. http://dx.doi. org/10.14210/nej.v15n1.p158-173

VASCONCELLOS, Vinicius Gomes de. Barganha e justiça criminal negocial: análise das tendências de expansão dos espaços de consenso no processo penal brasileiro. Dissertação (Mestrado em Direito) - Pontifícia Universidade Católica do Rio Grande do Sul, Porto Alegre, 2014.

VASCONCELLOS, Vinicius Gomes de. Barganha e justiça criminal negocial: análise das tendências de expansão dos espaços de consenso no processo penal brasileiro. São Paulo: IBCCRIM, 2015.

VASCONCELLOS, Vinicius Gomes de. Colaboração premiada e negociação na justiça criminal brasileira: acordos para a ampliação de sansão penal consentida pelo réu no processo penal. Revista Brasileira de Ciências Criminais, São Paulo, v. 166, p. 241-271, abr. 2020.

VIANA, Ulisses Schwarz. O direito no pensamento de Dworkin. In: ALMEIDA FILHO, Agassiz; LEITE, George Salomão; ABBOUD, Georges (orgs.). Ronald Dworkin: direito, política e pessoa humana. Florianópolis: Tirant Lo Blanch, 2018, p. 17-35. 


\section{Informações adicionais e declarações dos autores (integridade científica)}

Declaração de conflito de interesses (conflict of interest declaration): o autor confirma que não há conflitos de interesse na realização das pesquisas expostas e na redação deste artigo.

Declaração de autoria e especificação das contribuições (declaration of authorship): todas e somente as pessoas que atendem os requisitos de autoria deste artigo estão listadas como autores; todos os coautores se responsabilizam integralmente por este trabalho em sua totalidade.

Declaração de ineditismo e originalidade (declaration of originality): o autor assegura que o texto aqui publicado não foi divulgado anteriormente em outro meio e que futura republicação somente se realizará com a indicação expressa da referência desta publicação original; também atestam que não há plágio de terceiros ou autoplágio.

Dados do processo editorial

(http://www.ibraspp.com.br/revista/index.php/RBDPP/about/editorialPolicies)

- Recebido em: 09/03/2020

Equipe editorial envolvida

- Controle preliminar e verificação de plágio:

- Editor-chefe: 1 (VGV) 20/03/2020

- Avaliação 1: 28/03/2020

- Editor-assistente: 1 (FDL)

- Revisores: 3

- Avaliação 2: 30/03/2020

- Avaliação 3: 01/04/2020

- Decisão editorial preliminar: 17/04/2020

- Retorno rodada de correções: 28/04/2020

- Decisão editorial final: 03/05/2020 


\section{COMO CITAR ESTE ARTIGO:}

RESENDE, Augusto César Leite de. Direito (Subjetivo) ao Acordo de Não Persecução Penal e Controle Judicial: Reflexões Necessárias. Revista

Brasileira de Direito Processual Penal, Porto Alegre, vol. 6, n. 3, p. 1543-1582, set./dez. 2020. https://doi.org/10.22197/rbdpp.v6i3.347

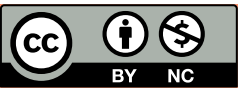

Esta obra está licenciada com uma Licença Creative Commons Atribuição-NãoComercial 4.0 Internacional. 